\title{
Anti-oxidant and Moisturizing Effects of Oil Extracted from Tenebrio molitor Larvae
}

\author{
Hae Ok Kim \\ Department of Nursing, Kyungnam University, Changwon-si, Gyeongsangnam-do, Korea
}

Corresponding author: Hae OK Kim, Department of Nursing, Kyungnam University, 7 Kyungnamdaehakro, Masanhappo-gu, Changwon-si, Gyeongsangnam-do 51767, Korea Tel.: +82552496346

Fax: +82 5059992140

Email: hok503@kyungnam.ac.kr

Received May 31, 2020

Revised July 27, 2020

Accepted August 10, 2020

Published September 30, 2020

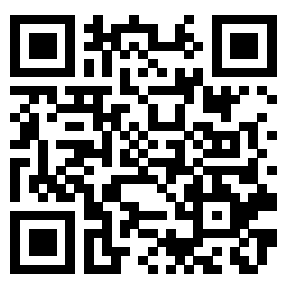

\begin{abstract}
Purpose: Recent widespread research into the biological effects of edible insects has occurred because they place a low burden on the environment, and the output offsets the effort. However, the anti-oxidant and moisturizing effects of their oils are relatively unknown. Tenebrio molitor larvae possess anti-adipogenic effects. This study investigated the anti-oxidant and moisturizing effects of Tenebrio molitor larvae oil (TMO) on HaCaT keratinocytes. Methods: We used a supercritical fluid extraction method to extract oil from Tenebrio molitor larvae. After purification, we evaluated the anti-oxidant activity of the TMO according to its 2,2-diphenyl-1-picrylhydrazyl (DPPH) radical scavenging activity, reduction potential, and metal-chelating activity. An 3-(4,5-dimethylthiazol-2-yl-2,5-diphenyltetrazolium bromide (MTT) assay was used to evaluate the cell viability of $\mathrm{HaCaT}$ keratinocytes treated with TMO. Reverse transcription-polymerase chain reaction assays were used to analyze the expression levels of ceramide synthase and ceramidase in TMO-treated HaCaT keratinocytes. Results: Treatment with $0.01 \%-0.2 \%$ TMO effectively scavenged DPPH radicals. In line with this, the TMO treatment showed a dose-dependent increase in reduction potential and metal-chelating activities. TMO treatment at concentrations of $0.01 \%-0.2 \%$ up to $0.2 \%$ for $72 \mathrm{~h}$ did not affect the viability of HaCaT keratinocytes. TMO treatment of HaCaT keratinocytes at nontoxic concentrations significantly upregulated the expression of ceramide synthase mRNA and downregulated the expression of ceramidase mRNA. Conclusion: TMO possesses anti-oxidant and moisturizing effects that show potential for use health products and cosmetics.
\end{abstract}

Keywords: Tenebrio molitor larvae, Anti-oxidant, Oxidative stress, Skin, Ceramide

\section{Introduction}

인체는 에너지를 생산하기 위하여 산화환원 과정을 반복하며 다 량의 활성 산소종 (reactive oxygen species, ROS)을 생성하고 이 는 자유 라디칼(free radicals)로 전환된다고 알려져 있다. 일부 활 성 산소는 일반적으로 조직의 항상성을 유지하면서 일반적으로 체 내의 항산화 방어 메커니즘에 의해 보호된다. 그러나 과도하게 생성 된 활성 산소는 체내의 항산화 균형을 무너뜨리고 산화적 스트레스 를 유발하여 피부노화 및 피부질환을 비롯한 각종 질병의 유발과 연 관되어 있음이 보고되었다(Lim et al., 2009; Salla et al., 2016) 또 한, 피부에 과도하게 생성된 활성산소는 색소 침착의 주요 원인으로 도 보고된 바 있어(Lee et al., 2011) 화장품 소재에서 항산화 활성 은 중요한 고려요소 중 하나로 생각된다(Jung \& Ryu, 2018; Lee \&
Ryu, 2019). 피부 노화를 억제하고 체내의 활성산소를 효율적으로 소거할 수 있는 항산화 소재는 크게 전자를 공여하는 기전과 수소를 공여하는 기전으로 구분할 수 있으며(Kim et al., 2016), 추가로 항 산화 소재의 metal chelating 활성은 Fenton reaction의 차단을 통 해 근본적으로 자유 라디컬의 생성을 억제시키는 데 유효한 것으로 알려져 있다(Kim et al., 2012). 따라서 향후 항산화 소재를 효율적 으로 활용하기 위해서는 위의 3 가지 라디컬 소거기전에 근거하여 항 산화 활성을 평가할 필요성이 있다.

피부의 탄력성과 부드럽고 촉촉한 느낌은 피부의 가장 외곽에 위 치한 표피의 각질층에 존재하는 수분에 의해 영향을 받는다. 각질층 의 수분 함량은 표피의 피지막과 각질층내에 존재하는 수용성 자연 보습인자(natural moisturizing factor, $\mathrm{NMF}$ )에 의해 결정된다. 즉, 표피의 수분 함량은 ceramide 및 자연 보습인자가 중요한 인자임을 
알 수 있다. 이전의 연구에서 표피의 피지막 손상은 ceramide 및 자 연 보습인자의 함량을 감소시키며, 습도와 기온이 하강하는 겨울이 나 노화의 진행 또한 ceramide 및 자연 보습인자의 함량을 감소시 키는 것으로 알려져 있다(Mizutani et al., 2009). 피부의 ceramide 는 ceramidase에 의해 sphingosine과 지방산으로 최종 분해되고 이들 분해 산물은 ceramide synthase에 의해 다시 ceramide로 전 환될 수도 있다. Ceramide의 생성은 ceramide synthase, serine palmitoyltransferase, cerebrosidase, 그리고 sphingomyelinase 등의 효소에 의해 촉진되며, ceramide의 감소는 ceramidase, glucosylceramide synthase 그리고 sphingomyelin synthase 등에 의해 영향을 받는다(Mizutani et al., 2009).

최근 곤충소재는 환경부담이 적다는 장점뿐만 아니라 동물들과 비교하여 에너지 소비량 및 탄소 배출량이 현저히 감축된다는 장점 이 있어 최근 바이오 산업 분야의 소재로서 각광받고 있다(Seo et al., 2019; Lee et al., 2019). 일본, 중국, 라오스, 타이, 그리고 베 트남 등의 국가에서는 식용곤충이 비교적 널리 보급되어 있으며 우 리나라는 현재 메뚜기, 누에, 갈색거저리 유충, 흰점박이꽃무지 유 충, 장수풍뎅이 유충 그리고 쌍별귀뚜라미는 식품원료로 이용 가능 하다. 하지만 이너뷰티 및 화장품 산업에 곤충소재를 적용한 사례 및 관련 연구는 미비한 실정이다. 최근 이너뷰티 산업이 크게 성장 하고 있음을 볼 때 식용곤충 소재는 이너뷰티 및 화장품 소재로서 적용 가능한지에 대한 검토가 요구된다.

갈색거저리 유충(Tenebrio molitor lavae)은 단백질과 불포화지 방산 함량이 높으며 비타민 및 무기질 등의 다양한 영양소를 함유하 고 있다. 최근 갈색거저리 유충 분말을 활용하여 식품 등에 적용하 는 연구가 보고되었으며(Park \& Kim, 2018), 갈색거저리 추출물의 항산화, 항염 및 항균 효과 등이 알려져 있다(Baek et al., 2018; Yu et al., 2016). 그러나 갈색거저리 유충 오일의 미용분야에 대한 연 구는 전무한 실정이다.

따라서 본 연구에서는 식용곤충인 갈색거저리 유충에서 초임계 추출을 통하여 오일성분을 추출하였으며, 추출된 갈색거저리 유충 오일(Tenebrio molitor lavae oil, TMO)의 DPPH 라디컬 소거활성, 환원력 및 metal chelating 활성 평가를 통해 항산화 활성을 분석하 고, 더불어 $\mathrm{HaCaT}$ keratinocytes에서 ceramide의 함량에 중요한 영향을 미치는 ceramide synthase 및 ceramidase의 유전자 발현을 분석하였다. 더 나아가 갈색거저리 유충 오일의 이너뷰티 및 화장품 소재로서의 활용 가능성에 대해 고찰하였다.

\section{Methods}

\section{1. 실험재료}

본 실험에 사용된 3-(4,5-dimethylthiazol-2-yl-2,5diphenyltetrazolium bromide (MTT), calcein, neocuproine, cupric sulfate, dimethylsulfoxide (DMSO) 그리고 vitamin C는 SigmaAldrich (USA)에서 구입하여 사용하였다. Dulbecco's modified Eagle's medium (DMEM), antibiotics cocktail 그리고 bovine calf serum (BCS)은 Welgene Inc. (Daegu, Korea)에서 구입하여 사 용하였다. RT-PCR 분석에 사용한 TRIzol ${ }^{\mathbb{}}$ 은 Life Technologies (Carlsbad, USA), PCR PreMix kit은 Bioneer (Daejeon, Korea) 에서 구입하여 사용하였다. 본 실험에서 사용된 인간유래 $\mathrm{HaCaT}$ keratinocytes는 Cell Lines Service (CLS, Germany)에서 구입하 여 사용하였다.

\section{2. 갈색거저리 유충 오일(TMO)의 제조}

본 실험에 사용된 갈색거저리 유충(Tenebrio molitor larvae) 건 조물(수분함량 $3.3 \%$ )은 경상남도 농업기술원에서 제공받아 사용하 였다. 갈색거저리 유충 건조물은 $60^{\circ} \mathrm{C}$ 의 온도에서 $300 \mathrm{bar}$ 의 압력 으로 초임계 추출기(SFX 3560, Lincoln, OR, USA)를 이용하여 3 $\mathrm{h}$ 동안 갈색거저리 유충 오일(Tenebrio molitor larvae oil, TMO)을 추출하였다. 추출된 $\mathrm{TMO}$ 는 이온교환수지 및 실리카겔 컬럼 크로마 토그래피를 통해 불순물을 제거한 후 정제된 것을 $-20^{\circ} \mathrm{C}$ 에 보관하 면서 이후 실험에 사용하였다.

\section{DPPH 라디칼 소거활성}

갈색거저리 유충 오일 $\mathrm{TMO}$ 의 항산화 활성은 $\mathrm{DPPH}$ 라디칼 소 거활성을 이용하여 평가하였다. $\mathrm{DPPH}$ 라디칼 소거능은 Chen 등 의 방법을 일부 변형하여 실험을 진행하였다(Chen et al, , 1998). $190 \mu \mathrm{M}$ 의 $\mathrm{DPPH}$ 에 $0.01 \%, 0.05 \%, 0.1 \%$ 그리고 $0.2 \%$ 농도의 $\mathrm{TMO} 10 \mu \mathrm{L}$ 를 가하여 $37^{\circ} \mathrm{C}$ 배양기에서 $30 \mathrm{~min}$ 동안 반응시킨 후, microplate reader (VersaMax; Molecular Devices, USA)를 이용하 여 $517 \mathrm{~nm}$ 에서 흡광도를 측정하였다. 본 실험에서는 수용성 항산화 제인 Vitamin C (L-ascorbic acid)를 양성 대조군으로 사용하였다. $\mathrm{TMO}$ 를 처리하지 않은 $\mathrm{DPPH}$ 를 대조군으로 하여 $\mathrm{TMO}$ 의 $\mathrm{DPPH}$ 라 디칼 소거활성(\% of control)을 계산하였다.

\section{4. 환원력 측정}

갈색거저리 유충 오일 $\mathrm{TMO}$ 의 시료의 환원력은 $\mathrm{Cu}^{2+}$ 로부터 $\mathrm{TMO}$ 에 의해 생성되는 $\mathrm{Cu}^{1+}$ 이온의 양을 측정함으로써 분석하였 다. $10 \mathrm{mM}$ phosphate buffer (pH 7.4)에 용해시킨 $100 \mu \mathrm{M} \mathrm{CuCl}_{2}$ 용액 $20 \mu \mathrm{L}$ 와 $10 \mathrm{mM}$ phosphate buffer에 용해시킨 $250 \mu \mathrm{M}$ neocuproine $80 \mu \mathrm{L}$ 를 혼합한 다음 $0.01 \%, 0.05 \%, 0.1 \%$ 그리고 $0.2 \%$ 의 $\mathrm{TMO}$ 를 각각 $40 \mu \mathrm{L}$ 를 첨가하고 실온에서 $1 \mathrm{~h}$ 동안 반응시 킨 뒤 최종 반응액을 $454 \mathrm{~nm}$ 에서 흡광도를 측정하였다. $\mathrm{TMO}$ 의 환원력은 $\mathrm{Cu}^{1+} /$ neocuproine의 extinction coefficient $\left(7.95 \times 10^{3}\right.$ $\left.\mathrm{M}^{-1} \mathrm{~cm}^{-1}\right)$ 를 사용하여 흡광도로부터 계산된 $\mathrm{Cu}^{1+}$ 의 농도로서 표시하 였다. 


\section{Metal chelating 활성}

갈색거저리 유충 오일 $\mathrm{TMO}$ 의 metal chelating 활성은 2 가 금속 이온 형광센서로 잘 알려진 calcein을 이용하여 Argirova 등의 방 법을 일부 변형하여 사용하였다(Argirova et al., 2003). 먼저 100 $\mathrm{mL}$ 의 $0.4 \mu \mathrm{M} \mathrm{CuSO}_{4}$ 용액과 $0.2 \mu \mathrm{M}$ calcein을 잘 혼합한 후 혼합 용액 $100 \mu \mathrm{L}$ 에 $0.01 \%, 0.05 \%, 0.1 \%$ 그리고 $0.2 \%$ 의 TMO $100 \mu \mathrm{L}$ 를 잘 섞어준 후 형광분석기에서 calcein의 형광 강도를 excitation wavelength $485 \mathrm{~nm}$, emission wavelength $535 \mathrm{~nm}$ 에서 측정하였 다. $\mathrm{CuSO}_{4}$ 를 첨가하지 않은 군을 대조군으로 하여 형광 강도(\% of control)를 계산하였다.

\section{6. 세포독성 평가}

갈색거저리 유충 오일 $\mathrm{TMO}$ 의 세포독성을 알아보고자 $\mathrm{MTT}$ assay를 실시하였다. HaCaT keratinocytes에 TMO를 0.01, 0.05, 0.1 , 그리고 $0.2 \%(\mathrm{v} / \mathrm{v})$ 의 농도로 $72 \mathrm{~h}$ 동안 처리한 후, MTT 시 약을 DMEM 배지에 희석하여 $200 \mu \mathrm{g} / \mathrm{mL}$ 농도로 제조하였다. 배 지를 완전히 제거한 후 준비된 $200 \mu \mathrm{g} / \mathrm{mL}$ 의 MTT 희석액을 처리 하여 $37^{\circ} \mathrm{C} \mathrm{CO}$ 배양기에서 $1 \mathrm{~h}$ 동안 배양하였으며, 반응 후 배지 를 완전히 제거하고 $300 \mu \mathrm{L}$ 의 $\mathrm{DMSO}$ 를 이용하여 각 세포의 불용 성 formazan을 녹여주었다. DMSO에 녹인 formazan을 microplate reader를 이용하여 $570 \mathrm{~nm}$ 에서 흡광도를 측정하였다. $\mathrm{TMO}$ 를 처리 하지 않은 $\mathrm{HaCaT}$ 세포를 대조군으로 하여 $\mathrm{TMO}$ 의 세포독성(\% of control)을 평가하였다.

\section{RT-PCR을 통한 유전자 발현 분석}

$\mathrm{HaCaT}$ keratinocytes에 $72 \mathrm{~h}$ 동안 $\mathrm{TMO}$ 를 0.01, 0.05, 그리 고 $0.1 \%(\mathrm{v} / \mathrm{v})$ 의 농도로 처리하고, Trizol ${ }^{\circledR}$ 을 이용하여 total RNA 를 추출한 후, chloroform을 $100 \mu \mathrm{L}$ 씩 첨가하여 $15 \mathrm{~s}$ 동안 잘 혼 합하였다. 원심 분리기(1580R, Seoul, Korea)를 이용하여 16,500 $\mathrm{rpm}, 25 \mathrm{~min}$ 의 조건에서 원심 분리하여 상층액을 얻은 후, 상층 액에 $250 \mu \mathrm{L}$ isopropanol을 첨가하고 $16,500 \mathrm{rpm}$ 에서 $20 \mathrm{~min}$ 동 안 재 원심 분리하여 $\mathrm{mRNA}$ 를 분리하고 정량한 뒤 $\mathrm{cDNA}$ 를 합성하 였다. Thermal cycler (T100; Bio-Rad, USA)를 이용하여 합성된 $\mathrm{cDNA}$ 로 $\mathrm{PCR}$ 을 수행한 후 아가로즈 젤에 전기영동하여 유전자 발 현수준을 분석하였다. 본 실험에서 사용된 대상 유전자들의 primer sequences는 Table 1 과 같다.

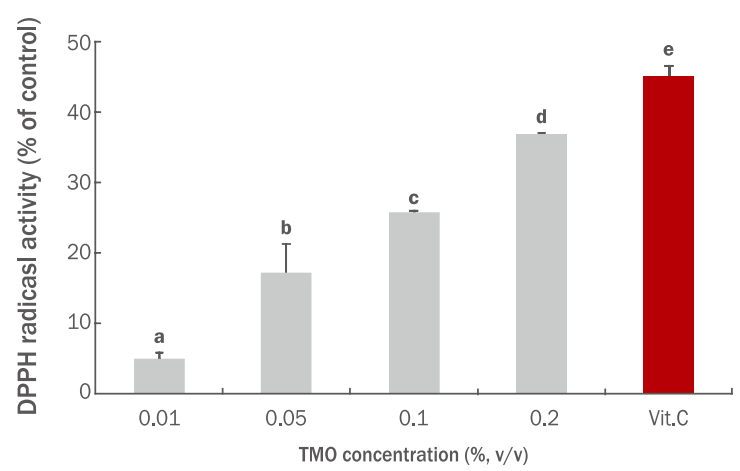

Figure 1. DPPH radical scavenging activity of TMO.

Vitamin $\mathrm{C}$ was used as a positive control. Different corresponding letters indicate significant differences $(p<0.5)$ by Duncan's test. The $\mathrm{IC}_{50}$ of TMO against DPPH radicals was $0.27 \%$. TMO, Tenebrio molitor larvae oil; Vit.C, vitamin C (500 $\mu \mathrm{g} / \mathrm{mL})$.

\section{8. 통계분석}

본 연구의 결과는 평균표준편차로 표현하였으며, 데이터의 통계처리는 Statistical Package for Social Science (SPSS, USA) 를 이용하여 분석하였다. 사후검증은 Duncan's test $(p<0.05)$ 또는 Student's $t$-test $(p<0.05)$ 방법에 의하여 각 구간의 유의성 차이를 검증하였다.

\section{Results and Discussion}

\section{1. $\mathrm{TMO}$ 의 $\mathrm{DPPH}$ 라디칼 소거활성}

$\mathrm{DPPH}$ 라디칼 소거능은 항산화 활성을 평가하는데 널리 이 용되는 실험법이다(Lee et al., 2019). DPPH 라디컬 소거능에 서 positive control로는 수용성 항산화제로 잘 알려진 비타민C (ascorbic acid)를 사용하였다. 비타민C는 $0.05 \%$ 의 농도에서 $\mathrm{DPPH}$ 라디칼을 $44.96 \%$ 소거하였다. $\mathrm{TMO}$ 는 $0.01 \%, 0.05 \%, 0.1 \%$, 그 리고 $0.2 \%$ 의 농도에서 각각 $4.77 \%, 17.04 \%, 25.60 \%$, 그리고 $36.87 \% \mathrm{DPPH}$ 라디칼을 소거하였다. $\mathrm{DPPH}$ 라디칼을 $50 \%$ 저해하 는 농도인 $\mathrm{TMO}$ 의 $\mathrm{IC}_{50}$ 은 $0.27 \%$ 로 나타났다(Figure 1 ). 이전 연구 들의 보고에 의하면 갈색거저리 유충 추출물의 $\mathrm{DPPH}$ 라디컬 소거 활성 및 아질산염 소거능이 보고되었다(Baek et al., 2017). 앞선

Table 1. Primer sequences for RT-PCR analysis

\begin{tabular}{lll}
\hline Name & \multicolumn{1}{c}{ Forward $\left(5^{\prime} \rightarrow 3^{\prime}\right)$} & Reverse $\left(5^{\prime} \rightarrow 3^{\prime}\right)$ \\
CERS & AGAGGCGAACACACGAAAGT & CCATATGGATAACACTTCTCG \\
ACER & TGTGATTACACGATGTGGATACCG & CTGCTTCTGACTTCCGGTGT \\
ACTB & GCAGGAGTATGACGAGTCCG & AGGGACTTCCTGTAACAATGC \\
\hline
\end{tabular}

CERS, ceramide synthase; ACER, alkaline ceramidase; ACTB, actin beta; RT-PCR, reverse transcription-polymerase chain reaction. 


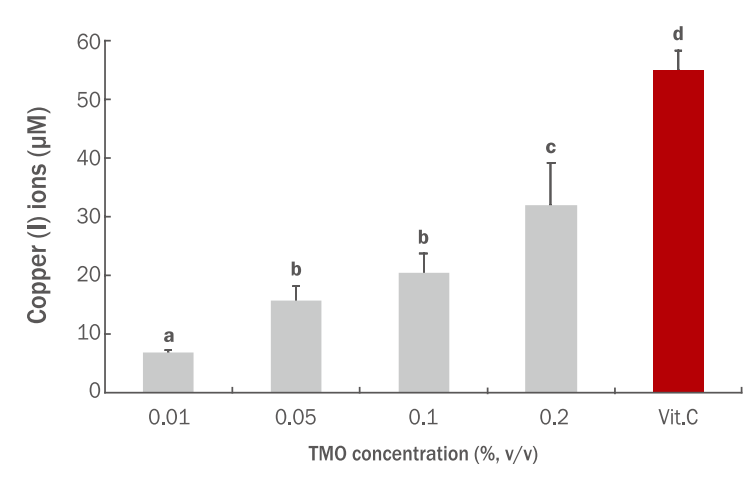

Figure 2. Reduction potential of TMO.

Vitamin C was used as a positive control. Different corresponding letters indicate significant differences $(p<0.5)$ by Duncan's test. TMO, Tenebrio molitor larvae oil; Vit.C, vitamin C (100 $\mu \mathrm{g} / \mathrm{mL})$.

연구에서 갈색거저리 유충의 $70 \%$ 에탄올 추출물이 사용되었으며, $1 \mathrm{mg} / \mathrm{mL}$ 에서 $17.22 \%, 5 \mathrm{mg} / \mathrm{mL}$ 에서 $66.79 \%, 10 \mathrm{mg} / \mathrm{mL}$ 에서 $81.17 \%$ 의 DPPH radical 소거능을 나타냈다고 보고하였다. 본 연 구에서는 갈색거저리 유충의 오일 성분만을 분리하여 직접적인 비 교는 어렵지만 갈색거저리 유충의 단백질 및 지방 성분은 항산화 활 성을 나타내는 것으로 추측된다. 갈색거저리 유충을 flavourzyme, alcalase, neutrase 단백가수분해 효소로 분해하였을 때 alcalase 가 수분해물>flavourzyme 가수분해물>neutrase 가수분해물 순으로 $\mathrm{DPPH}$ 라디컬 소거활성이 높게 나타났다고 보고되었다(Yu et al., 2017). 지금까지 식용곤충과 관련된 연구는 곤충의 단백질 또는 펩 타이드 구성 및 이들의 생리활성에 대한 연구가 대다수이며(Cho et al., 2020), 갈색거저리 유충의 오일 성분에 대한 연구는 상대적으 로 미비한 실정이다. 건조된 갈색거지리 유충은 약 $53 \%$ 의 단백질, $28 \%$ 의 지방 그리고 $5 \%$ 의 섬유소로 구성되어 있다고 알려져 있다 (Mariod, 2020). 현재 갈색거저리 유충의 단백질 성분은 활용되고 있는 방면 지방 성분은 대다수가 폐기되고 있는 실정이므로 이의 기 능성이 체계적으로 검증된다면 갈색거저리 유충의 오일 성분 또한 기능성 소재로서 충분히 활용될 수 있을 것이라 생각된다. 본 결과 는 갈색거저리 유충의 오일성분이 체내 활성산소의 증가를 억제를 통한 천연 항산화 소재로 활용될 수 있는 가능성을 시사한다.

\section{2. $\mathrm{TMO}$ 의 환원력}

갈색거저리 유충 오일 $\mathrm{TMO}$ 의 전자공여능을 $\mathrm{Cu}^{2+}$ 이온을 $\mathrm{TMO}$ 가 $\mathrm{Cu}^{1+}$ 이온으로 환원시키는 능력을 측정하여 평가하였다. $\mathrm{TMO}$ 의 환원력을 측정한 결과, $\mathrm{TMO}$ 는 $0.01 \%-0.2 \%$ 에서 농도 의존적으로 환원력이 증가하였다. $0.01 \%, 0.05 \%, 0.1 \%$, 그리고 $0.2 \%$ 의 TMO 는 각각 $6.88,15.56,20.25$, 그리고 31.76 으로 나타났다(Figure 2). 양성 대조군으로 사용된 $0.01 \%$ 의 비타민C는 54.62 의 환원력을 나타냈다. 이전의 연구에서 상엽에 존재하는 flavonoids류의 일종인

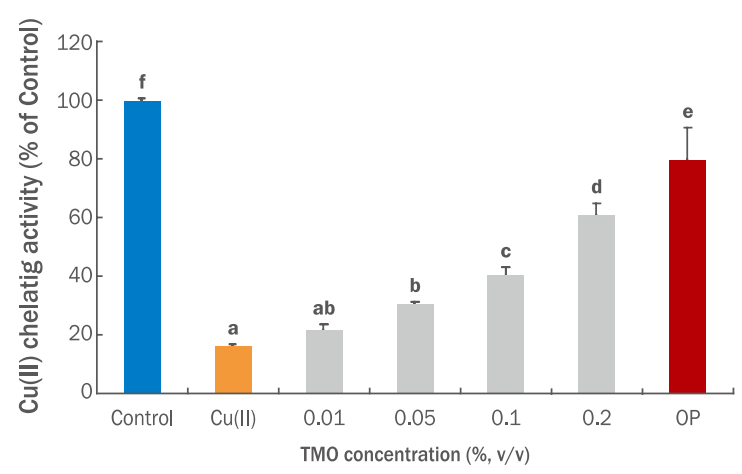

Figure 3. Metal-chelating activity of TMO.

OP, a well-known metal chelator, was used as a positive control. Different corresponding letters indicate significant differences $(p<0.5)$ by Duncan's test. TMO, Tenebrio molitor larvae oil; OP, O-phenanthroline $(100 \mu \mathrm{M})$.

flavonol이 환원력을 통한 전자공여를 통해 항산화 활성을 나타낸다 고 보고 한 바 있으며(Kim \& Jang, 2011), 환원력을 통한 전자공여 는 항산화 활성의 주요한 작용기전 중 하나라 알려져 있다(Huang et al., 2005). 따라서 갈색거저리 유충 오일 TMO는 hydroxyl 라디 컬 $(\mathrm{HO} \cdot)$ 등의 활성산소를 전자공여능을 통해 안정화시키는데 기여 할 수 있으며, 향후 이너뷰티 및 화장품 개발에 있어 항산화 소재로 충분히 활용될 수 있을 것이라 생각된다.

\section{TMO의 metal chelating 활성}

갈색거저리 유충 오일 $\mathrm{TMO}$ 의 metal chelating은 calcein을 이 용한 형광분석법을 이용하였다. 항산화 소재의 metal chelating 활 성은 $\mathrm{H}_{2} \mathrm{O}_{2}$ 와 2가 전이금속과의 반응 (Fenton-like reaction)에 의 해 생성되는 유리 라디칼의 생성을 억제 또는 차단할 수 있는 지의 가능성을 보여준다. TMO의 metal chelating 활성을 측정한 결과, $0.01 \%, 0.05 \%, 0.1 \%$ 그리고 $0.2 \%$ 의 $\mathrm{TMO}$ 는 농도 의존적으로 $\mathrm{Cu}^{2+}$ 이온에 대한 metal chelating 활성이 증가하였다. $0.01 \%, 0.05 \%$, $0.1 \%$ 그리고 $0.2 \%$ 의 $\mathrm{TMO}$ 는 대조군 대비 각각 $16.56 \%, 22.08 \%$, $40.41 \%$ 그리고 $60.86 \%$ 로 나타났다(Figure 3). 2가 전이금속의 metal chelating로 잘 알려진 $100 \mu \mathrm{M}$ 의 O-phenanthroline (OP)의 metal chelating 활성은 대조군 대비 $80.06 \%$ 로 나타났다. 항산화 소재로 잘 알려진 quercetin, kaempferol, rutin 및 luteolin의 항산 화 활성에 있어 metal chelating이 중요하게 작용한다고 기 보고된 바 있으며(Leopoldini et al., 2006; Brown et al., 1998), HepG2 세포에서 kaempferol의 metal chelating은 세포의 nuclear factor erythroid-2-related factor 2 (Nrf2)를 상향 조절하여 세포내 항산 화 활성을 증진시킨다고 보고되었다(Kim et al., 2012). 본 연구에 서 $\mathrm{TMO}$ 의 항산화 활성은 환원력과 metal chelating 활성이 복합적 으로 작용하는 것으로 추측된다. 


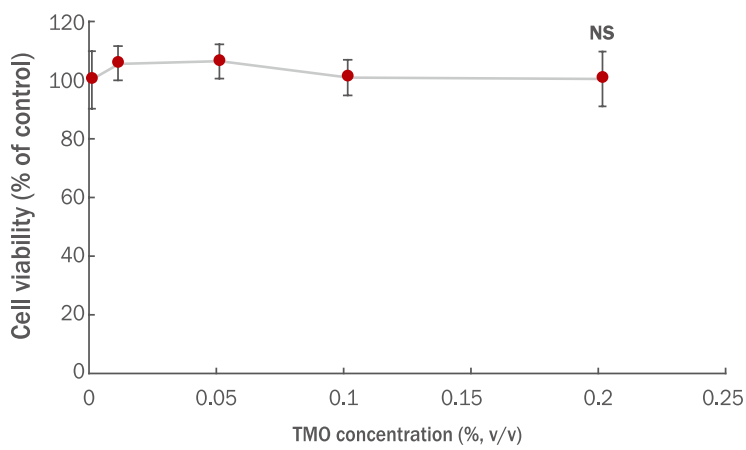

Figure 4. Cytotoxic effect of TMO.

The viability of HaCaT keratinocytes was evaluated by MTT assay following treatment with $0.01 \%, 0.05 \%, 0.1 \%$, and $0.2 \%$ of TMO for 72 h. TMO, Tenebrio molitor larvae oil; NS, not significant; MTT, 3-(4,5-dimethylthiazol-2-yl-2,5-diphenyltetrazolium bromide.

\section{HaCaT keratinocytes에서 TMO의 세포독성 평가}

$\mathrm{TMO}$ 가 HaCaT keratinocytes에서 독성을 나타내는지 알아보 기 위하여 MTT assay를 실시하여 세포생존율을 분석하였다. TMO 를 $0.01 \%, 0.05 \%, 0.1 \%$ 그리고 $0.2 \%$ 의 농도로 $\mathrm{HaCaT}$ 세포에 72 $\mathrm{h}$ 처리하였을 때, $\mathrm{TMO}$ 를 처리한 $\mathrm{HaCaT}$ 세포의 생존율은 각각 $105.23 \%, 106.10 \%, 100.55 \%$ 그리고 $100.07 \%$ 였다(Figure 4). 결 과적으로 $0.2 \%$ 이하의 $\mathrm{TMO}$ 처리는 $\mathrm{HaCaT}$ 세포에서 유의적인 세 포독성을 나타내지 않았으므로, 이후 실험에서는 $0.01 \%-0.2 \%$ 농 도의 $\mathrm{TMO}$ 를 사용하였다.

\section{TMO 처리가 HaCaT keratinocytes의 ceramide synthase 및 ceramidase 발현에 미치는 영향}

$\mathrm{HaCaT}$ keratinocytes에서 $\mathrm{TMO}$ 를 $72 \mathrm{~h}$ 처리한 후 ceramide synthase와 ceramidase의 유전자 발현을 분석하였다. 그 결과, $\mathrm{TMO}$ 를 $0.01 \%, 0.05 \%, 0.1 \%$ 그리고 $0.2 \%$ 처리하였을 때 대조군의 $\mathrm{HaCaT}$ 세포와 비교하여 ceramide synthase의 mRNA 발현수준이 현저히 증가한 것을 확인하였으며, 반대로 ceramidase의 발현은 농 도 의존적으로 감소하는 것을 확인하였다(Figure 5).

피지막의 지질 성분 중 ceramide의 생성 감소는 표피장벽을 파괴 하고 이는 수용성자연 보습인자의 감소를 유발하며 결과적으로 표 피 수분의 손실을 증가시킨다. 따라서, ceramide의 생성과 감소는 피부의 보습에 중요한 영향을 미친다. 피부의 충분한 수분량은 피부 의 표면을 매끄럽게 하고 탄력의 유지 및 피부결을 좌우하는 중요한 요소이다. 건강한 표피의 각질층은 $15-20 \%$ 의 수분을 함유하고 있 으며 수분이 $10 \%$ 이하로 떨어지면 피부가 건조해지고 윤기와 탄력 이 없어져 주름을 증가시킨다(Elam et al., 1963).

피부의 ceramide는 ceramidase에 의해 sphingosine과 지방산으 로 최종 분해되고 이들 분해 산물은 ceramide synthase에 의해 다

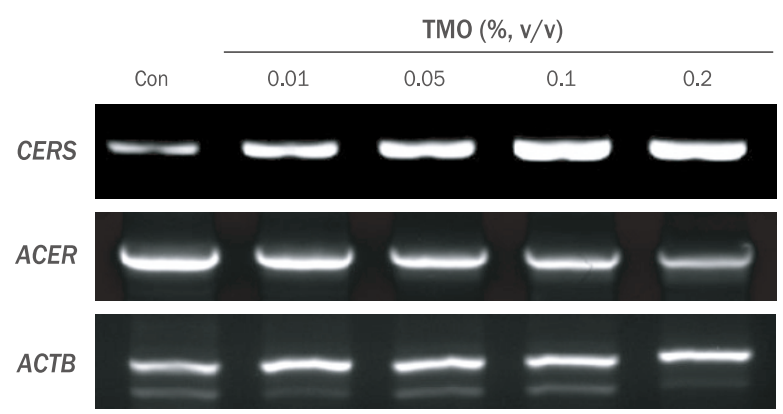

Figure 5. Effect of TMO treatment on mRNA expression levels of HaCaT keratinocytes.

Ceramide synthase and ceramidase were analyzed by RT-PCR. $\beta$-actin was used as an internal control. TMO, Tenebrio molitor larvae oil.

시 ceramide로 전환될 수도 있다. Ceramide는 ceramide synthase 에 의해 sphingosine과 지방산을 이용하여 합성되며, ceramide의 의 생성은 또한 serine palmitoyltransferase, cerebrosidase, 그 리고 sphingomyelinase 등의 효소에 의해 촉진된다 (Mizutani et al., 2009). 반대로 ceramide는 ceramidase에 의해 sphingosin 과 지방산으로 분해되며 glucosylceramide synthase 그리고 sphingomyelin synthase 등에 의해 영향을 받는다 (Mizutani et al., 2009). 이전의 연구에서 ceramidase가 결핍된 Acer $1^{-/-}$마우 스의 피부에서 높은 수준의 ceramide 함량이 관찰된 것을 볼 때 ceramidase의 억제는 피부의 ceramide 증가를 통해 피부의 보습유 지에 도움이 될 수 있다는 것을 뜻한다(Liakath-Ali et al., 2016). Ceramide의 함량을 조절하는 두 효소의 활성 및 직접적인 피부의 보습 개선 정도를 측정하는 것이 더 바람직하나, 현재는 식용곤충에 서 분리한 오일의 보습소재로서의 가능성을 스크리닝 하는 초기 단 계이기 때문에 향후 해당 부분에 대한 추가실험이 요구된다. 위의 결과는 피부의 각질세포에서 $\mathrm{TMO}$ 가 ceramide의 생성 및 유지에 도 움을 줄 수 있는 소재로서의 가능성을 보여주는 결과로 생각된다.

\section{Conclusions}

우리나라는 메뚜기, 누에, 갈색거저리 유충, 흰점박이꽃무지 유 충, 장수풍뎅이 유충 그리고 쌍별귀뚜라미가 식품원료로 이용 가능 한 식용곤충이다(장수풍뎅이 유충과 쌍별귀뚜라미는 한시적 식품 원료). 현재 식용곤충은 전세계적으로 큰 관심을 받고 있지만 이에 대한 연구는 대다수가 곤충의 단백질 조성 및 특성, 가수분해를 통 한 기능성 펩타이드의 발굴 및 식용곤충을 활용한 식품개발 등으로 한정적으로 진행되고 있는 실정이다. 또한 식용곤충의 단백질 함량 
은 $50 \%$ 이상(건조중량)으로 식용곤충에서 주로 단백질을 분리하고 $25 \%$ 이상의 지방 성분은 대부분 폐기되고 있는 실정이다. 특히 갈 색거저리 유충의 지방 성분은 불포화 지방산의 함량이 높고 지용성 비타민을 다량 함유하고 있다는 장점이 있어 식용곤충의 지방 성분 에 대한 과학적 근거가 마련된다면 이는 폐기되는 자원의 고부가가 치화에 기여할 수 있을 뿐만 아니라, 화장품 개발에도 충분히 유용 한 소재로 활용될 수 있을 것이라 생각된다.

본 연구에서는 갈색거저리 유충에서 초임계 추출을 통하여 오일 성분을 분리 정제하였으며, 추출한 갈색거저리 유충 오일 $\mathrm{TMO}$ 의 $\mathrm{DPPH}$ 라디칼 소거활성, 환원력 평가 및 metal chelating을 분석하 여 항산화 활성을 평가하였다. 그 결과 $\mathrm{TMO}$ 는 농도 의존적이며 유 의적인 항산화 활성을 나타냈으며, $\mathrm{TMO}$ 의 항산화 활성은 전자공 여 및 2 가 금속이온의 chelating을 통하여 라디칼을 소거할 수 있음 을 알 수 있었다. 또한 $\mathrm{TMO}$ 의 보습활성을 알아보기 위하여 인간유 래 HaCaT keratinocytes에서 피부 보습의 주요한 인자인 ceramide 의 함량에 중요한 영향을 미치는 ceramide synthase와 ceramidase 의 유전자 발현을 분석하였다. $\mathrm{TMO}$ 는 $\mathrm{HaCaT}$ 세포독성이 나타나 지 않은 농도 범위에서 ceramide synthase의 유전자 발현을 증가시 켰으며 반대로 ceramidase의 유전자 발현은 감소시켰다. 이러한 연 구결과는 $\mathrm{TMO}$ 가 항산화 및 보습 소재로서 이너뷰티 및 화장품 개 발에 충분히 활용될 수 있다는 가능성을 보여주는 결과라 생각된다. 그러나 현재의 연구는 in vitro 수준의 연구결과로서 더 나아가 전임 상 및 임상연구를 통하여 $\mathrm{TMO}$ 의 활성 및 기전에 대한 구체적인 연 구가 추가적으로 요구된다.

\section{Acknowledgements}

이 연구결과물은 2019학년도 경남대학교 학술진흥연구비 지원 에 의한 것임.

\section{Author's contribution}

HOK designed and performed all experimental investigations, analyzed data, and wrote the manuscript.

\section{Author details}

Hae Ok Kim (Associate Professor), Department of Nursing, Kyungnam University, 7 Kyungnamdaehak-ro, Masanhappo-gu, Changwon-si 51767, Gyeongsangnamdo, Korea.

\section{References}

Argirova MD, Ortwerth BJ. Activation of protein-bound copper ions during early glycation: study on two proteins. Archives of Biochemistry and Biophysics, 420: 176-184, 2003.

Baek M, Seo M, Kim MA, Yun EU, Hwang JS. The antioxidant activities and hair-growth promotion effects of Tenebrio molitor larvae extracts (TMEs). Journal of Life Science, 27: 1296-1275, 2017.

Baek M, Seo M, Lee JH, Kim IW, Kim MA, Hwang JS. Osteoblastogenic activity on Locusta migratoria ethanol extracts on pre-osteoblastic MG-63 cells. Journal of Life Science, 28: 1448-1454, 2018.

Brown JE, Khodr H, Hider RC, Rice-Evans CA. Structural dependence of flavonoid interactions with $\mathrm{Cu}^{2+}$ ions: Implications for their antioxidant properties. Biochemistry Journal, 330: 1173-178, 1998.

Chen HM, Muramoto K, Yamauchi F, Fujimoto K, Nokihara K. Antioxidative properties of histidine-containing peptides designed from peptide fragments found in the digests of a soybean protein. Journal of Agricultural and Food Chemistry, 46: 49-53, 1998.

Cho KH, Kang SW, Yoo JS, Song DK, Chung YH, Kwon GT, Kim YY. Effects of mealworm (Tenebrio molitor) larvae hydrolysate on nutrient ileal digestibility in growing pigs compared to those of defatted mealworm larvae meal, fermented poultry by-product, and hydrolyzed fish soluble. Asian-Australasian Journal of Animal Sciences, 33: 490-500, 2020.

Elam R, Goodwin D, Williams K. Optical properties of the human epidermis. Nature, 198: 1001-1002, 1963.

Huang D, Ou B, Prior RL. The chemistry behind antioxidant capacity assays. Journal of Agricultural and Food Chemistry, 53: 1841-1856, 2005.

Jung YH, Ryu MJ. Anti-oxidative and anti-inflammatory effects of Codonopsis lanceolate skin extracts. Asian Journal of Beauty and Cosmetology, 16: 347-357, 2018.

Kim GN, Jang HD. Flavonol content in the water extract of the mulberry (Morus alba L.) leaf and their antioxidant capacities. Journal of Food Science, 76: C869-C873, 2011.

Kim GN, Kim ES, Kwon YI, Jang HD. Potential mechanism of kaempferol against $\mathrm{Cu}^{2+}$-induced oxidative stress through chelating activity and regulation of nuclear factor-erythroid-2-related factor 2 signaling. Food Science 
and Biotechnology, 21: 1496-1475, 2012.

Kim RH, Song JH, Shon MS, Chun KS, Choi SU, Kim GN. Evaluation of water extract prepared from Chrysanthemum indicum Linne as nutria-cosmetic and cosmetic material in vitro model. Asian Journal of Beauty and Cosmetology, 14: 78-88, 2016.

Lee SM, Han JS, Kim AJ. Quality evaluation of Perilla seed Gangjung added with mealworm powder. Asian Journal of Beauty and Cosmetology, 17: 187-197, 2019.

Lee SY, Kim HJ, Choi SW. Study on the antioxidant activity of Geranium nepalense subsp. thunbergii extract. Journal of the Society of Cosmetic Scientists of Korea, 37: 61-66, 2011.

Lee YS, Ryu MJ. Antioxidant effects of Cinnamomum cassia bark extract and its effectiveness as a cosmetic ingredient. Asian Journal of Beauty and Cosmetology, 17: 69-80, 2019.

Leopoldini M, Russo N, Chiodo S, Toscano M. Iron chelation by the powerful antioxidant flavonoid quercetin. Journal of Agricultural and Food Chemistry, 54: 6343-6351, 2006.

Liakath-Ali K, Vancollie VE, Lelliott CJ, Speak AO, Lafont D, Protheroe HJ, Ingvorsen C, Galli A, Green A, Gleeson D, et al. Alkaline ceramidase 1 is essential for mammalian skin homeostasis and regulating whole-body energy expenditure. The Journal of Pathology, 239: 374-383, 2016.

Lim JK, Kang HJ, Kang SN, Lee BY. Antioxidant and antimicrobial activities of various solvent fractions of fine ginseng root. Food Science and Biotechnology, 18: 513518, 2009.

Mariod AA. Nutrient composition of mealworm (Tenebrio molitor). In: African edible insects as alternative scource of food, oil, protein and bioactive components. Adam Mariod A (ed.), Springer, Cham, pp275-280, 2020.

Mizutani Y, Mitsutake S, Tsuji K, Kihara A, Igarashi Y. Ceramide biosynthesis in keratinocyte and its role in skin function. Biochimie, 91: 784-790, 2009.

Park KH, Kim GY. Quality and characteristic of manufacturing Sunsik with edible insect (mealworm). Culinary Science and Hospitality Research, 24: 13-23, 2018.

Salla S, Sunkara R, Ogutu S, Walker LT, Verghese M. Antioxidant activity of papaya seed extracts against $\mathrm{H}_{2} \mathrm{O}_{2}$ induced oxidative stress in HepG2 cells. LWT-Food Science and Technology, 66: 293-297, 2016.

Seo M, Baek M, Lee JH, Lee HJ, Kim IW, Kim SY, Hwang JS, Kim MA. Osteoblastogenic activity of Tenebrio molitor larvae oil on the MG-63 osteoblastic cell. Journal of Life Science, 29: 1027-1033, 2019.

Yu JM, Jang JY, Kim HJ, Cho YH, Kim DI, Kwon OJ, Cho YJ, An BJ. Antioxidant capacity and Raw 264.7 macrophage anti-inflammatory effect of the Tenebrio molitor. Korean Journal of Food Preservation, 24: 890-898, 2016.

Yu MH, Lee HS, Cho HR, Lee SO. Enzymatic preparation and antioxidant activities of protein hydrolysates from Tenebrio molitor larvae (Mealworm). Journal of the Korean Society of Food Science and Nutrition, 46: 435441, 2017. 


\section{국문초록}

\section{갈색거저리 유충 오일의 항산화 및 보습활성}

김혜옥

경남대학교 간호학과, 경상남도 창원시, 한국

목적: 최근 식용곤충은 환경부담이 적다는 장점뿐만 아니라 동물들과 비교하여 에너지 소비량 및 탄소 배출량이 현저히 감축된다 는 장점이 있어 최근 바이오 산업 분야의 소재로서 각광받고 있다. 식용곤충의 몇몇 생리활성이 보고되었지만 오일 성분에 대한 연 구는 상대적으로 미미한 실정이다. 따라서, 본 연구에서는 식용곤충의 일종인 갈색거저리 유충에서 오일을 분리 및 정제하고 이의 항산화 및 보습활성을 평가하고자 한다. 방법: 갈색거저리 유충에서 초임계 추출을 통하여 오일 성분(TMO)을 분리하였다. TMO의 $\mathrm{DPPH}$ 라디컬 소거활성, 환원력 평가 그리고 metal chelating 활성을 평가하여 항산화 활성을 분석하였다. HaCaT keratinocytes에 서 세포독성은 MTT 실험법으로 분석하였다. Ceramide synthase 및 ceramidase의 유전자 발현은 RT-PCR 방법을 통해 분석하였 다. 결과: 본 실험에서 $0.01 \%, 0.05 \%, 0.1 \%$ 그리고 $0.2 \%$ 의 $\mathrm{TMO}$ 는 농도 의존적이며 유의적으로 $\mathrm{DPPH}$ 라디칼을 소거하였다. 또한 환원력 및 metal chelating 활성 역시 농도 의존적이며 유의적으로 증가하는 것을 관찰하였다. HaCaT keratinocytes에 $72 \mathrm{~h} \mathrm{TMO}$ 를 처리하였을 때 유의적인 세포독성이 관찰되지 않았으며, 이후 세포실험에서는 $0.01 \%-0.2 \%$ 농도의 $\mathrm{TMO}$ 를 사용하였다. $\mathrm{HaCaT}$ keratinocytes에 $72 \mathrm{~h}$ 동안 $\mathrm{TMO}$ 를 처리하였을 때 ceramide synthase 발현이 증가하였으며, 반대로 ceramidase의 발현은 감소함을 관찰하였다. 결론: 본 연구결과는 $\mathrm{TMO}$ 가 항산화 및 항비만 활성을 가진 이너뷰티 및 화장품 소재로 충분히 활용될 수 있음을 시사 한다.

핵심어: 갈색거저리 유충, 항산화, 산화적 스트레스, 피부, 세라마이드

이 연구결과물은 2019학년도 경남대학교 학술진흥연구비 지원에 의한 것임.

\section{참고문헌}

김령현, 송지혜, 손명수, 전계식, 최선욱, 김교남. 감국 물 추출물의 미용기능식품 및 화장품 소재로서의 가능성 탐색. 아 시안뷰티화장품학술지, 14: 78-88, 2016.

박기홍, 김건영. 식용곤충(갈색거저리)을 첨가한 선식의 품질특성. 한국조리학회지, 24: 13-23, 2018.

백민희, 서민철, 김미애, 윤은영, 황재삼. 갈색거저리 유충 추출물의 항산화 활성 및 모발 성장 촉진 효과. 생명과학회지,

27: 1269-1275, 2017.

백민희, 서민철, 이준하, 김인우, 김미애, 황재삼. 풀무치 에탄올 추출물이 $\mathrm{MG}-63$ 조골세포 분화에 미치는 영향. 생명과 학회지, 28: 1448-1454, 2018.

서민철, 백민희, 이준하, 이화정, 김인우, 김선영, 황재삼, 김미애. 갈색거저리 유충 오일이 $\mathrm{MG}-63$ 조골세포 분화에 미치

는 영향. 생명과학회지, 29: 1027-1033, 2019.

이선미, 한정순, 김애정. 밀웜 분말 들깨강정의 품질 평가. 아시안뷰티화장품학술지, 17: 187-197, 2019.

이선영, 김현주, 최신욱. 이질풀 추출물의 항산화 효능에 관한 연구. 대한화장품학회지, 37: $61-66,2011$.

이영숙, 유민정. 계피 추출물의 항산화 효과 및 화장품소재의 응용. 아시안뷰티화장품학술지, 17: 69-80, 2019.

유미희, 이효선, 조혜린, 이승욱. 갈색거저리 유충 단백가수분해물의 제조 및 항산화 활성. 한국식품영양과학회지, 46: 435-441, 2017. 유재묘, 장재윤, 김현정, 조용훈, 김동인, 권오준, 조영제, 안봉전. 갈색거저리(Tenebrio Molitor)의 항산화능과 Raw

264.7 대식세포의 항염증 효과. 한국식품저장유통학회지, 23: 890-898, 2016.

정윤희, 유민정. 더덕 껍질 추출물의 항산화 및 항염증 효과. 아시안뷰티화장품학술지, 16: 347-357, 2018. 


\section{中文摘要}

\section{黄粉虫幼虫油的抗氧化和保湿作用}

金惠玉

庆南大学护理学科, 庆尚南道昌原市, 韩国

目的：由于食用昆虫对环境造成的负担很小，因此最近对食用昆虫的生物效应进行了广泛的研究。然而，它们的 油的抗氧化和保湿作用是相对未知的。这项研究调查了黄粉虫幼虫油（Tenebrio molitor larvae oil，TMO) 对 HaCaT角质形成细胞的抗氧化和保湿作用。方法: 采用超临界流体提取方法从黄粉虫幼虫中提取油。纯化 后，根据其2,2-diphenyl-1-picrylhydrazyl (DPPH)自由基清除活性，还原电位和金属螯合活性评估了TMO的 抗氧化活性。使用3-(4,5-dimethylthiazol-2-yl-2,5-diphenyltetrazolium bromide (MTT)分析法评估经TMO处 理的 $\mathrm{HaCaT}$ 角质形成细胞的细胞存活率，采用逆转录聚合酶链反应分析法分析。结果：在该实验中， $0.01 \%$, $0.05 \%, 0.1 \%$ 和 $0.2 \%$ 的TMO是浓度依赖性的，并且可以显着清除DPPH自由基。另外，观察到还原能力和金 属螯合活性也是浓度依赖性的并且显着增加。用TMO处理HaCaT角质形成细胞72小时，未观察到明显的细胞毒 性, 随后的细胞实验中使用 $0.01 \%-0.2 \%$ 的TMO浓度。在 HaCaT角质形成细胞中用TMO处理 72 小时, 神经酰胺 合酶的表达增加, 而神经酰胺酶的表达减少。结论: 这项研究的结果表明, TMO可以充分用作具有抗氧化和抗肥 胖作用的内在美容和化妆品材料。

关键词: 黄粉虫幼虫, 抗氧化剂, 氧化应激, 皮肤, 神经酰胺 
